\title{
Clinicopathologic and Molecular Profiles of Microsatellite Unstable Barrett Esophagus- associated Adenocarcinoma
}

\section{Citation}

Farris, Alton B., Elizabeth G. Demicco, Long Phe Le, Karin E. Finberg, Julie Miller, Rajni Mandal, Junya Fukuoka, et al. 2011. Clinicopathologic and molecular profiles of microsatellite unstable Barrett esophagus-associated adenocarcinoma. The American Journal of Surgical Pathology 35(5): 647-655.

\section{Published Version}

doi:10.1097/PAS.0b013e31820f18a2

\section{Permanent link}

http://nrs.harvard.edu/urn-3:HUL.InstRepos:12490654

\section{Terms of Use}

This article was downloaded from Harvard University's DASH repository, and is made available under the terms and conditions applicable to Other Posted Material, as set forth at http:// nrs.harvard.edu/urn-3:HUL.InstRepos:dash.current.terms-of-use\#LAA

\section{Share Your Story}

The Harvard community has made this article openly available.

Please share how this access benefits you. Submit a story.

Accessibility 


\title{
Clinicopathologic and Molecular Profiles of Microsatellite Unstable Barrett Esophagus-associated Adenocarcinoma
}

\author{
Alton B. Farris, III, MD, ${ }^{*} \dagger$ Elizabeth G. Demicco, MD, PhD, * Long Phe Le, MD, PhD,* \\ Karin E. Finberg, MD, PhD, + Julie Miller, BS, ${ }^{*}$ Rajni Mandal, MD, ${ }^{*}$ Junya Fukuoka, MD, $\S$ \\ Cynthia Cohen, MD, $\dagger$ Henning A. Gaissert, MD,\| Lawrence R. Zukerberg, MD,* \\ Gregory Y. Lauwers, MD, ${ }^{*}$ A. John Iafrate, MD, PhD, and Mari Mino-Kenudson, MD*
}

\begin{abstract}
Microsatellite instability (MSI) has been reported in various tumors, with colon cancer as the prototype. However, little is known about MSI in Barrett esophagus (BE)-associated adenocarcinoma. Thus, the aim of this study was to compare the clinicopathologic and molecular features of BE-associated adenocarcinomas with and without MSI. The study cohort consisted of 76 patients with BE-associated adenocarcinomas (66 male, 10 female), with a mean age of 65.1 years. Immunohistochemistry (IHC) for MLH1, MSH2, MSH6, PMS2, and CD3 and in situ hybridization for Epstein-Barr virus-encoded RNA were performed. MLH1 and PMS2 expression was lost by IHC in 5 cases (6.6\%); of these, 5 showed high-level MSI (MSI-H) by polymerase chain reaction assay, and 4 showed $h M L H 1$ promoter methylation. Histologically, tumors with MSI-H were heterogenous and included conventional adenocarcinomas with tumor-infiltrating lymphocytes $(n=1)$, medullary carcinoma $(n=2)$, signet ring cells $(\mathrm{n}=1)$, and signet ring cell and mucinous components $(\mathrm{n}=1)$. Compared with tumors negative for MSI by IHC, BE-associated adenocarcinomas with MSI-H were associated with older patient age $(P=0.0060)$, lymphovascular invasion $(P=0.027)$, and significantly larger numbers of tumor-infiltrating lymphocytes $(P<0.0001)$. However, there was no statistical difference in overall survival between the 2 groups ( $P=0.285$ ). In conclusion, MSI-H is uncommon in BE-associated adenocarcinomas, but is associated with clinicopathologic features fairly similar to sporadic microsatellite unstable colorectal cancers. Given the growing evidence that indicates lack of benefits from adjuvant therapy with fluorouracil in the colonic counterpart, it may be important to identify MSI-H in BE-associated adenocarcinomas.
\end{abstract}

Key Words: Barrett esophagus, esophageal adenocarcinoma, microsatellite instability, histology, medullary carcinoma, tumorinfiltrating lymphocyte

From the Departments of *Pathology; \|Thoracic Surgery, Massachusetts General Hospital and Harvard Medical School, Boston, MA; $\dagger$ Department of Pathology, Emory University School of Medicine, Atlanta, GA; \$Department of Pathology, Duke University Medical Center, Durham, NC; and §Toyama Medical University, Toyama, Japan.

Duality of interest: None.

Correspondence: Mari Mino-Kenudson, MD, Department of Pathology, Massachusetts General Hospital and Harvard Medical School, Boston, MA (e-mail: mminokenudson@partners.org).

Copyright (C) 2011 by Lippincott Williams \& Wilkins
(Am J Surg Pathol 2011;35:647-655)

E sophageal cancer is a neoplasm with a poor prognosis E that has attracted more attention in recent years. In 2010 , it was predicted that well over 16,000 new cases of esophageal cancer would be diagnosed with an estimated death toll of approximately 14,500 patients. ${ }^{2}$ Since the mid-1970s, the incidence of esophageal adenocarcinoma has risen $>350 \%$ among white men and has surpassed the incidence of squamous cell carcinoma. ${ }^{11}$ Overall, esophageal adenocarcinoma has a poor prognosis, with $<50 \%$ of patients surviving 1 year after diagnosis. ${ }^{11}$ Over the last 2 decades, multiple epidemiologic studies on the etiology of esophageal adenocarcinoma have found gastroesophageal reflux disease and increased body mass index to be the strongest risk factors. ${ }^{11,42}$ These are also well-known risk factors for Barrett esophagus (BE) ${ }^{42}$ and the majority of esophageal adenocarcinomas arises in a background of $\mathrm{BE}$. $^{7}$

Multiple molecular pathways are involved in the development of adenocarcinoma of the esophagus, including derangements in tumor suppressor genes such as $p 53$ and p16. In addition, deregulated activity of protooncogenes, regulatory genes that control proliferation through such mechanisms as inhibition of apoptosis, also contributes to the development of carcinoma of the esophagus [eg, $E G F$, EGFR, TGF, c-erbB2 (HER2/neu), src, c-myc, and BRAF]. A stepwise accumulation of molecular alterations leads to progression from metaplasia to dysplasia to adenocarcinoma. Mitotic and apoptotic checkpoint genes (eg, cyclins, BCL-2, and Fas/Fas ligand) may also be defective in esophageal carcinoma. Furthermore, it is thought that esophageal adenocarcinomas possess disruptions of cell-cell adhesion molecules and their ligands (such as E-cadherin and $\beta$-catenin and cathepsin B and CD44). ${ }^{12,19}$

Microsatellite instability (MSI) caused by defective mismatch repair (MMR) is another mechanism that has been shown in the pathogenesis of esophageal carcinoma, particularly esophageal adenocarcinoma. In normal cells, MMR genes correct errors in DNA sequence that arise primarily during DNA replication. Inactivation of both alleles of the recessive repair genes leads to defective DNA repair and a genome-wide accumulation of 
mutations, including the defects in tumor suppressor genes and protooncogenes. Tandem repeat sequences (microsatellites) are susceptible to DNA mismatches, and MSI is a key feature of MMR defects. ${ }^{12,19}$ Several studies of MSI in esophageal carcinomas have been carried out, and most of these indicate that high-level MSI (MSI-H) status has a low prevalence in esophageal adenocarcinoma. The prevalence of MSI, either MSI-H or "MSI-low," has been reported to be approximately $5 \%$ to $10 \% .^{13,20,27,43}$

The frequency of MSI-H, however, has been reported inconsistently in BE-associated adenocarcinoma, ${ }^{13,20,27,43}$ and little is known about the clinicopathologic and molecular features and the biological behavior of microsatellite unstable BE-associated adenocarcinoma. Thus, the aims of this study were to further clarify the frequency of MSI and to characterize BE-associated adenocarcinomas with or without MSI.

\section{MATERIALS AND METHODS}

\section{Patient Population}

From a prospectively collected database at Massachusetts General Hospital, a series of 272 esophagectomies and esophagogastrectomies for adenocarcinoma performed between January 2000 and May 2008 were identified. Of those, patients treated with chemotherapy and/or radiation therapy $(\mathrm{n}=83)$, photodynamic therapy $(n=2)$, or endoscopic mucosal resection $(n=4)$ before resection were excluded. Of the remaining 183 cases, 108 were epicentered in the cardia or distal esophagus and showed intestinal metaplasia of the distal esophagus (Barrett esophagus) in the resection specimen and/or preoperative esophageal biopsies. Of those, 32 cases with a tumor confined to the mucosa (intramucosal adenocarcinoma) were excluded, and the remaining 76 cases formed our study cohort. Institutional review board approval was procured for testing and review of existing pathologic specimens and for clinical chart review.

\section{Histologic Evaluation}

All cases were fixed in $10 \%$ buffered formalin and were embedded in paraffin by standard procedures. Representative sections of tumor and adjacent mucosa stained with hematoxylin and eosin were evaluated in each case for the following study variables: size of tumor, depth of invasion $(\mathrm{pT})$, nodal metastases $(\mathrm{pN})$, presence of distant metastases (pM), presence of lymphovascular invasion, large vessel (venous) invasion, perineural invasion, resection margin status, histologic grade $(\mathrm{pG})$ and histomorphologic features of tumor, and the background mucosa. The American Joint Committee on Cancer Staging Manual, 7th edition, ${ }^{3}$ was used to define and categorize TNM cancer stage and histologic grade. The histomorphology of tumors was classified as adenosquamous carcinoma, conventional adenocarcinoma (papillary and/or glandular), medullary carcinoma [solid growth with tumor-infiltrating lymphocytes (TILs)], mucinous carcinoma, or signet ring cell carcinoma. Medullary, mucinous, and signet ring cell carcinomas were defined as carcinomas with $>50 \%$ of the relevant histology.

\section{Tissue Microarray Construction}

In each case, 2 to 5 tissue cores that represented each histologic subtype were harvested from the original paraffin blocks, and a total of six 2-mm-core tissue microarray (TMA) blocks were constructed. Each TMA block also included normal gastric body/fundic mucosa, cardiac-type mucosa, and Barrett mucosa as controls and 5 cores of nongastroesophageal junction cancers.

\section{Immunohistochemical Analysis}

Immunohistochemical studies were carried out on TMA $5 \mu \mathrm{m}$ sections using Ventana Benchmark (Ventana Medical Systems, Tucson, AZ) or Dako AutostainerPlus automated stainers (Dako Corporation, Santa Barbara, CA). Monoclonal antibodies against 4 MMR proteins, namely hMLH1 [Becton Dickinson (BD) Biosciences, San Jose, CA], hMSH2 (BD Biosciences or EMD Chemicals, Gibbstown, NJ), hMSH6 (BD Biosciences), and hPMS2 (BD Biosciences), were applied. Protein expression was collectively evaluated in all of the tumor cells seen in multiple cores from each case. Complete negative expression in any of the MMR proteins, with adjacent normal mucosa or stromal/lymphoid cells exhibiting intact nuclear staining, was considered to be positive for loss of MMR proteins. Cases determined to potentially have loss of MMR proteins on the TMA were confirmed by staining whole sections of tumor with immunohistochemistry for all 4 MMR proteins. Cases determined to have loss of MMR proteins on whole sections were examined by molecular microsatellite analysis.

CD3 immunostaining (Ventana) was performed to evaluate TILs. CD3-positive T cells infiltrating between tumor cells were counted in all available cores using an Olympus BX40 microscope (total area of 40x field equal to $0.94 \mathrm{~mm}^{2}$ ), and the mean CD3-positive cells/highpower field (HPF) was calculated in each case.

For the purpose of this study, in situ hybridization was also performed on all available TMA sections with an oligonucleotide probe specific for Epstein-Barr virus (EBV)-encoded RNA (EBER) (Ventana or PNA PROBE, Dako Corporation).

\section{Molecular Microsatellite Analysis}

Normal and tumor tissues were manually microdissected from serial, 5- $\mu$ m-thick unstained sections of formalin-fixed, paraffin-embedded tissue (3 slides; approximately $1 \mathrm{~cm}^{2}$ tissue per slide). The tissue was deparaffinized in xylene and rehydrated in 100\% ethanol. DNA was extracted using the Puregene DNA Purification Kit (Gentra Systems, Minneapolis, MN).

Polymerase chain reaction (PCR) was performed in $20 \mu \mathrm{L}$ volumes using $1 \mathrm{X}$ Platinum Taq PCR buffer, $200 \mu \mathrm{M}$ dNTPs, $2.0 \mathrm{mM} \mathrm{MgCl}_{2}, 0.4 \mu \mathrm{M}$ primers, and $1.0 \mathrm{U}$ of Platinum Taq polymerase (all from Invitrogen, Carlsbad, CA), with $40 \mathrm{ng}$ of tumor or normal DNA as template. Primer sets consisted of the 5 reference 
panel markers recommended by the National Cancer Institute, ${ }^{4}$ with $5^{\prime}$ phosphoramidite fluorescent labeling of forward primers as follows: BAT-25 (NED), BAT-26 (6-FAM), D5S346 (VIC), D17S250 (6-FAM), and D2S123 (VIC). The primer sequences for D2S123 were 5'-AACATTGCTGGAAGTTCTGG-3' (forward) and 5'-GTGTCTTGACTTTCCACCTATGGGACTG-3' (reverse). Primer sequences for the remaining loci were identical to those previously described ${ }^{23}$ except that a $5^{\prime}$-GTGTCTT sequence was added to each reverse primer to facilitate nontemplate adenylation of the $3^{\prime}$ end of the forward strand.

PCR was performed in a Mastercycler ep (Eppendorf, Hamburg, Germany) with an initial denaturing step at $94^{\circ} \mathrm{C}$ for 5 minutes. This was followed by 38 cycles of denaturing at $94^{\circ} \mathrm{C}$ for 30 seconds, annealing at either $50^{\circ} \mathrm{C}$ or $55^{\circ} \mathrm{C}$ for 30 seconds, and extension at $72^{\circ} \mathrm{C}$ for 30 seconds. The final elongation step was at $72^{\circ} \mathrm{C}$ for 10 minutes. PCR products were pooled and fractionated by size using an Applied Biosystems (Foster City, CA) 3730 DNA Analyzer with GeneMapper software. Microsatellite loci at which tumor DNA showed a novel allele profile not present in the corresponding normal DNA were classified as MSI unstable. MSI-H was defined as 2 or more of the 5 examined microsatellite markers showing instability, whereas MSI-low was defined as only 1 marker showing instability.

\section{Analysis of $h M L H 1$ Promoter Methylation}

A methylation assay was performed when MMR analysis by immunohistochemistry (IHC) was suggestive of a loss of MLH1. The methylation status in the $\mathrm{CpG}$ island $5^{\prime}$ to the transcription start site of the $h M L H 1$ gene was examined by methylation-specific PCR analysis, based on the sequence differences between methylated and nonmethylated DNA after bisulfite modification (EZ DNA Methylation Kit; Zymo Research, Orange, CA). Converted DNA was amplified by PCR using methylation-specific primers in a total volume of $20 \mu \mathrm{L}$ containing $2 \mu \mathrm{L}$ of $10 \times$ reaction buffer, $4.0 \mathrm{mM} \mathrm{MgCl}_{2}, 200 \mu \mathrm{M}$ dNTPs, $10 \mathrm{pmol}$ forward and reverse primers, and $0.2 \mu \mathrm{L}$ of Platinum Taq polymerase. Amplification was performed in an Eppendorf Mastercycler Gradient and entailed an initial denaturation at $94^{\circ} \mathrm{C}$ for 4 minutes followed by 40 cycles of denaturation at $94^{\circ} \mathrm{C}$ for 30 seconds, annealing at $62^{\circ} \mathrm{C}$ for 30 seconds, extension at $72^{\circ} \mathrm{C}$ for 60 seconds, and a final extension for 10 minutes at $72^{\circ} \mathrm{C}$.

\section{Mutational Analysis of the BRAF Genes}

Tumor DNA samples of MSI-high tumors were analyzed for recurrent point mutations in $B R A F$ codon V600 using the single base extension SNaPshot assay (Applied Biosystems, ABI, Foster City, CA). BRAF exon 16 , which contains the target codons, was amplified in a 4plex PCR reaction $(4 \mu \mathrm{L}$ total containing $5 \mathrm{pmoL}$ of forward and reverse primers, $200 \mu \mathrm{M}$ dNTP, $2.0 \mathrm{mM}$ $\mathrm{MgCl}_{2}, 0.2 \mathrm{U}$ Platinum Taq Polymerase, and approximately 5 to $10 \mathrm{ng}$ of DNA; all reagents from Invitrogen,
Carlsbad, CA). Thermocycling conditions were as follows: $95^{\circ} \mathrm{C}$ for 2 minutes, $\left(94^{\circ} \mathrm{C}\right.$ for $15 \mathrm{~s}, 58^{\circ} \mathrm{C}$ for $30 \mathrm{~s}$, $\left.72^{\circ} \mathrm{C} \quad 15 \mathrm{~s}\right) \times 38$ cycles. Unincorporated primers and dNTPs were eliminated from the PCR reactions by adding $2 \mu \mathrm{L}$ of an exonuclease I (Exo) and shrimp alkaline phosphatase (SAP) mixture [USB Web, Cleveland, $\mathrm{OH}, 1$ volume of Exo ( 10 units $/ \mu \mathrm{L})$ to 10 volumes of SAP (1 unit/ $\mu \mathrm{L})$ ], and incubating at $37^{\circ} \mathrm{C}$ for 45 minutes followed by 15 minutes inactivation at $80^{\circ} \mathrm{C}$. The extension primer pool (approximately 14 total pmol in $1 \mu \mathrm{L})$ mixed with RR mix ( $3 \mu \mathrm{L}, \mathrm{ABI})$ was added directly to the cleaned up PCR amplification product for single base extension: $96^{\circ} \mathrm{C}$ for 30 seconds, $\left(96^{\circ} \mathrm{C}\right.$ for $10 \mathrm{~s}, 50^{\circ} \mathrm{C}$ for $5 \mathrm{~s}, 60^{\circ} \mathrm{C}$ for $\left.30 \mathrm{~s}\right) \times 35$ cycles. The extension primers were designed to interrogate 11 bases corresponding to the 4 target codons in either the forward or the reverse direction (F or R): BRAF c.1798F and c.1799R. The extension products were treated with SAP using the same procedure as the Exo-SAP step and were then analyzed using the ABI 3500xL Genetic Analyzer (Applied Biosystems, Foster City, California). Detailed protocol and primer information are available on request and will be reported separately (Le, Iafrate, et al, unpublished protocol).

\section{Data Analysis}

For all statistical analyses, Epi Info Version 3.5.1 (Centers for Disease Control and Prevention, Atlanta, GA) was used. All $P$ values were 2 -sided, and statistical significance was set at $P<0.05$. For categorical data, the $\chi^{2}$ test was carried out, and for continuous variables, the unpaired Student $t$ test was applied.

\section{RESULTS}

\section{Study Cohort}

The study cases consisted of 76 BE-associated adenocarcinomas from 66 male and 10 female patients, with a mean age of 65.1 years $(\mathrm{SD}, 11.1 \mathrm{y})$. American Joint Committee on Cancer tumor and lymph node stages were $\mathrm{pT} 1 / 2 / 3 / 4=24 / 16 / 36 / 0$ and $\mathrm{pN} 0 / 1 / 2 / 3=37 /$ $18 / 11 / 10$, distant metastases were $\mathrm{pM} 1 / \mathrm{x}=3 / 73$, and histology grades were $\mathrm{pG} 1 / 2 / 3=4 / 33 / 39$; the mean tumor size was $4.0 \mathrm{~cm}(\mathrm{SD}, 1.9 \mathrm{~cm})$. Lymphovascular invasion was noted in $40(53 \%)$ cases, perineural invasion in $30(39 \%)$ cases, and venous invasion in $18(24 \%)$ cases. Resection margins were involved by tumor in $10(13 \%)$ cases. The histomorphologic types included adenosquamous cell carcinoma $(\mathrm{n}=1)$, conventional adenocarcinoma $(n=73)$, and medullary carcinoma $(n=2)$. Of the 73 tumors with conventional adenocarcinoma, focal mucinous differentiation was seen in 6 cases, focal signet ring cell features were seen in 4 cases, both mucinous and signet ring cell components were seen in 9 cases, and focal medullary growth was seen in 1 case. No case was strictly classified into signet ring cell carcinoma or mucinous carcinoma. 


\section{Clinicopathologic Profile of Microsatellite Unstable BE-associated Adenocarcinoma}

Of 76 BE-associated adenocarcinomas in the study, $5(6.6 \%)$ cases showed concurrent MLH1 and PMS2 loss by IHC (Table 1). The remaining 71 cases showed preserved nuclear expression of MLH1, PMS2, MSH2, and MSH6. All the 5 cases with loss of MLH1 and PMS2 by IHC were confirmed to have MSI-H by PCR assay (Table 1). Representative results from MLH1 IHC and MSI PCR are shown in Figures 1 and 2, respectively.

Selected clinicopathologic and follow-up data of the 5 patients with microsatellite unstable (MSI-H) BE-associated adenocarcinoma are shown in Table 1. Compared with 71 patients with a MSI IHC-negative $\left(\mathrm{MSI}^{-}\right)$tumor, those with a MSI-H tumor were more likely to be older (76y vs 64 y, $P=0.006)$. Although a MSI-H tumors were more likely to be large $(5.3 \mathrm{~cm}$ vs $3.9 \mathrm{~cm}, P=0.163)$ with lymphatic invasion $(100 \%$ vs $49 \%, P=0.056)$, the difference did not reach statistical significance, and there was no difference in nodal status between the 2 groups (Table 2).

The histomorphology of MSI-H tumors consisted of conventional adenocarcinoma with TILs $(n=1)$, medullary carcinoma $(\mathrm{n}=1)$, and adenocarcinoma with heterogenous histology $(n=3)$ [with a medullary component $(n=1)$, with a signet ring cell component $(n=1)$, and with signet ring cell and mucinous components $(n=1)]$, recapitulating the colonic counterpart (Fig. 1), and was in stark contrast to $\mathrm{MSI}^{-}$tumors that mostly exhibited conventional adenocarcinoma $(P=0.027)$ (Table 2$)$.

TILs were significantly increased in MSI-H tumors compared with $\mathrm{MSI}^{-}$tumors (Table 2). The average count of CD3-positive $\mathrm{T}$ cells infiltrating within tumor cells was 42.9/HPF (range, 21 to 95) for MSI-H tumors and 5.2/HPF (range, 0-102) for $\mathrm{MSI}^{-}$tumors $(P<$ $0.0001)$. Interestingly, in the $\mathrm{MSI}^{-}$group, a significant increase in TILs ( $>20$ TILs/HPF) was seen in only 1 case with medullary carcinoma, which was the sole case positive for EBER. It should be noted that no other case, either MSI-H or $\mathrm{MSI}^{-}$, exhibited EBER.

\section{Molecular Profile of Microsatellite Unstable BE-associated Adenocarcinoma}

Of the 5 MSI-H tumors, all but 1 showed $h M L H 1$ promoter methylation (Fig. 3), but none of the examined cases exhibited $B R A F$ V600E mutations.

\section{Survival of Microsatellite Unstable BE-associated Adenocarcinoma}

Of the 4 patients with a MSI-H tumor and available follow-up data, 1 died of sepsis during the postoperative period, and 2 died of disease at 12 months and 23 months after operation. The remaining patient was alive without disease after esophagogastrectomy for T2N0 adenocarcinoma and no adjuvant therapy (Table 1). There was no statistical difference in overall survival between patients with a MSI-H BE-associated adenocarcinoma and those with a $\mathrm{MSI}^{-}$tumor (median survival: $23 \mathrm{mo}$ vs $32 \mathrm{mo}, P=0.285$ ).

\section{DISCUSSION}

MSI-H has been reported $h M L H 1$ in approximately $15 \%$ of colorectal, gastric, and endometrial cancers and in lower frequencies in a minority of other tumors. ${ }^{45}$ Several studies have collectively reported that defective MMR occurs in a small subset; 4.7\% (13 of 274) of BEassociated adenocarcinomas. ${ }^{12,13,19,20}$ In this study, we not only confirmed MSI-H in an appreciable minority, $6.6 \%$ of invasive adenocarcinomas arising in the background of $\mathrm{BE}$, but also showed their association with unique clinicopathologic features.

Among the prototype and most extensively studied tumors, that is MSI-H colorectal cancers, the vast majority is associated with sporadic methylation of the $h M L H 1$ promoter. However, germline mutations in MMR genes also predispose to MSI-H colorectal cancers in patients with hereditary nonpolyposis colorectal cancer (HNPCC). ${ }^{14,22,39}$ It has been well documented that MSI-H colorectal cancers, both sporadic and syndromic, have a better overall prognosis compared with microsatellite stable colorectal cancers. ${ }^{39}$ Growing evidence suggests that patients with

TABLE 1. Characteristics of Microsatellite Unstable BE-associated Adenocarcinomas

\begin{tabular}{|c|c|c|c|c|c|c|c|c|c|c|c|c|}
\hline Case & $\begin{array}{l}\text { Age } \\
(\mathbf{y})\end{array}$ & Sex & $\begin{array}{l}\text { Personal } \\
\text { History of } \\
\text { Cancer }\end{array}$ & $\begin{array}{l}\text { Family } \\
\text { History of } \\
\text { Cancer } \\
\end{array}$ & $\begin{array}{c}\text { Tumor } \\
\text { Size }(\mathbf{c m}) \\
\end{array}$ & pT & pN & Histology & $\begin{array}{c}\text { TIL } \\
(/ \text { HPF }) \\
\end{array}$ & MLH1* & $\begin{array}{c}\mathbf{F} / \mathbf{U} \\
(\mathbf{m o}) \dagger\end{array}$ & Status \\
\hline 1 & 78 & M & None & None & 5.5 & 3 & 1 & $\begin{array}{l}\text { Adenocarcinoma with } \\
\text { mucinous and signet ring cell } \\
\text { components }\end{array}$ & 21 & Positive & 22.7 & DOD \\
\hline 2 & 75 & M & None & $\begin{array}{l}\text { Breast cancer } \\
\text { (mother) }\end{array}$ & 7.5 & 3 & 1 & Medullary carcinoma & 95 & Negative & 0.5 & DOC \\
\hline 3 & 67 & M & None & None & 2.8 & 2 & 0 & $\begin{array}{l}\text { Adenocarcinoma with a signet } \\
\text { ring cell component }\end{array}$ & 23 & Positive & 11.7 & DOD \\
\hline 5 & 83 & $\mathrm{~F}$ & None & None & 4.5 & 2 & 0 & $\begin{array}{l}\text { Conventional adenocarcinoma } \\
\text { with tumor-infiltrating } \\
\text { lymphocytes }\end{array}$ & 33 & Positive & 21.7 & AWOD \\
\hline
\end{tabular}

*hMLH1 promoter methylation

$\dagger$ Follow-up.

AWOD indicates alive without disease; DOC, dead of complication; DOD, dead of disease; F, female; Lost, lost to follow-up; M, male. 

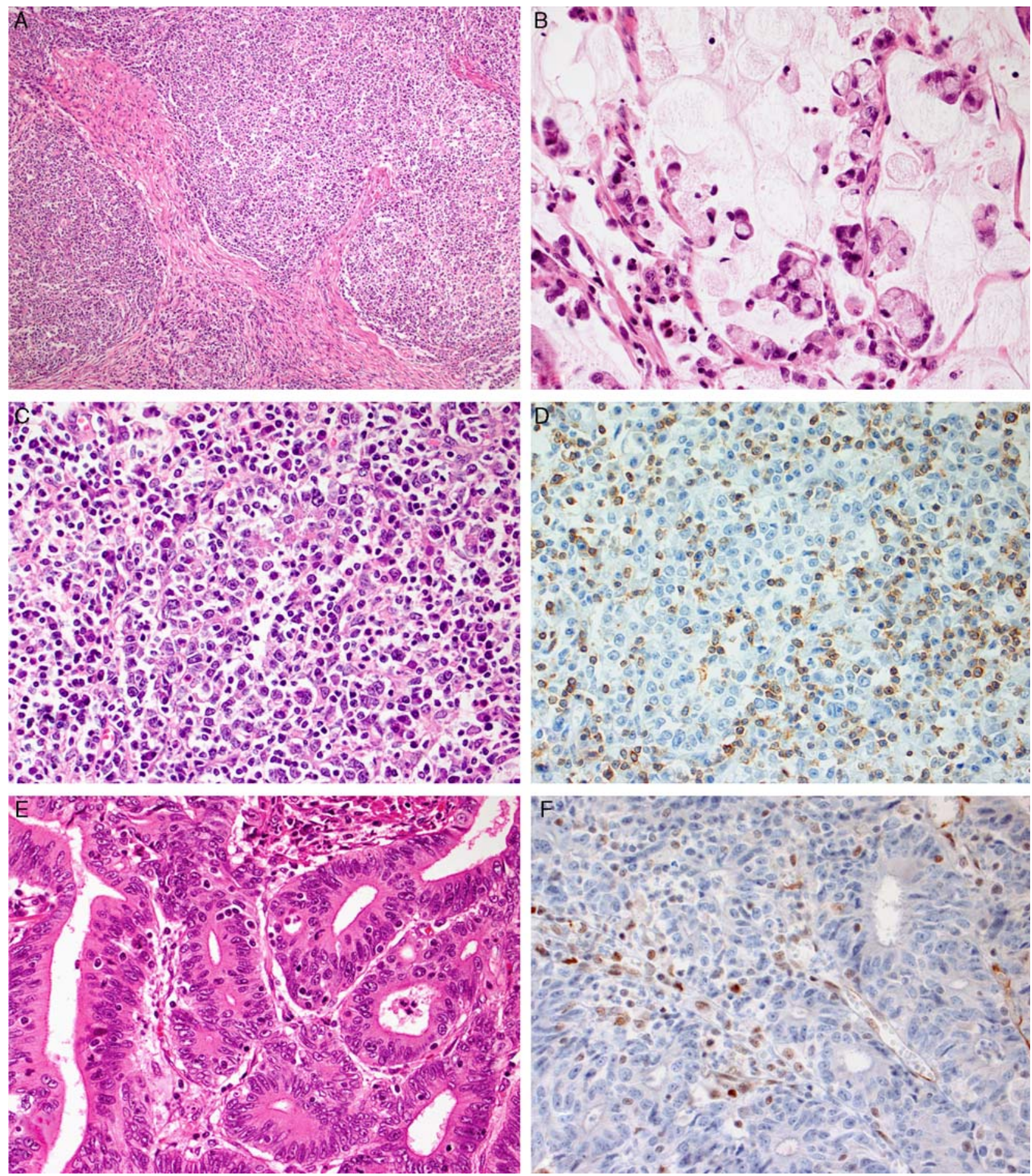

FIGURE 1. Microsatellite unstable BE-associated adenocarcinomas with a heterogenous morphology. A, Medullary carcinoma showing a pushing border (magnification, $\times 100$ ). B, Adenocarcinoma with signet ring cell and mucinous components (magnification, $\times 400$ ). $C$ and D, Medullary carcinoma with abundant lymphocytes infiltrating a solid growth of carcinoma cells (magnification, $\times 400$. C: Hematoxylin and Eosin stain, D: CD3 stain). E and F, Conventional adenocarcinoma with tumor infiltrating lymphocytes (TILs). MLH1 immunostain (F) highlights nuclei of stromal cells and TILs, but those of the tumor cells are devoid of staining (magnification, $\times 400$ ).

MSI-H colorectal carcinomas do not benefit from adjuvant chemotherapy with fluorouracil (5-FU), which has been commonly used for the treatment of both colorectal cancer and esophageal adenocarcinoma. ${ }^{36,37}$ On account of these clinical differences and the magnitude of importance in recognizing patients with HNPCC, both clinicians and 


\section{A $\quad$ BAT25}

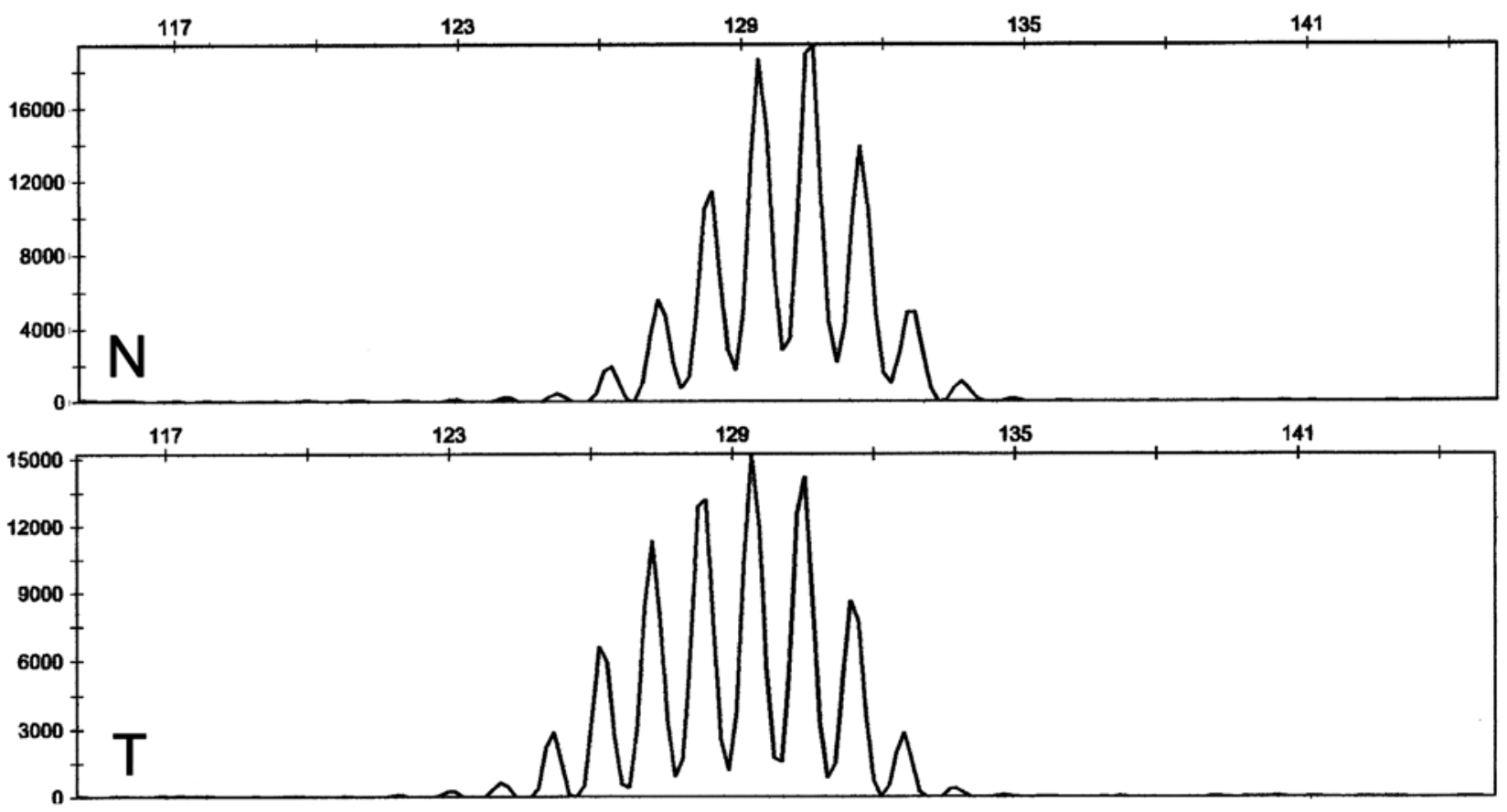

B

D17S250
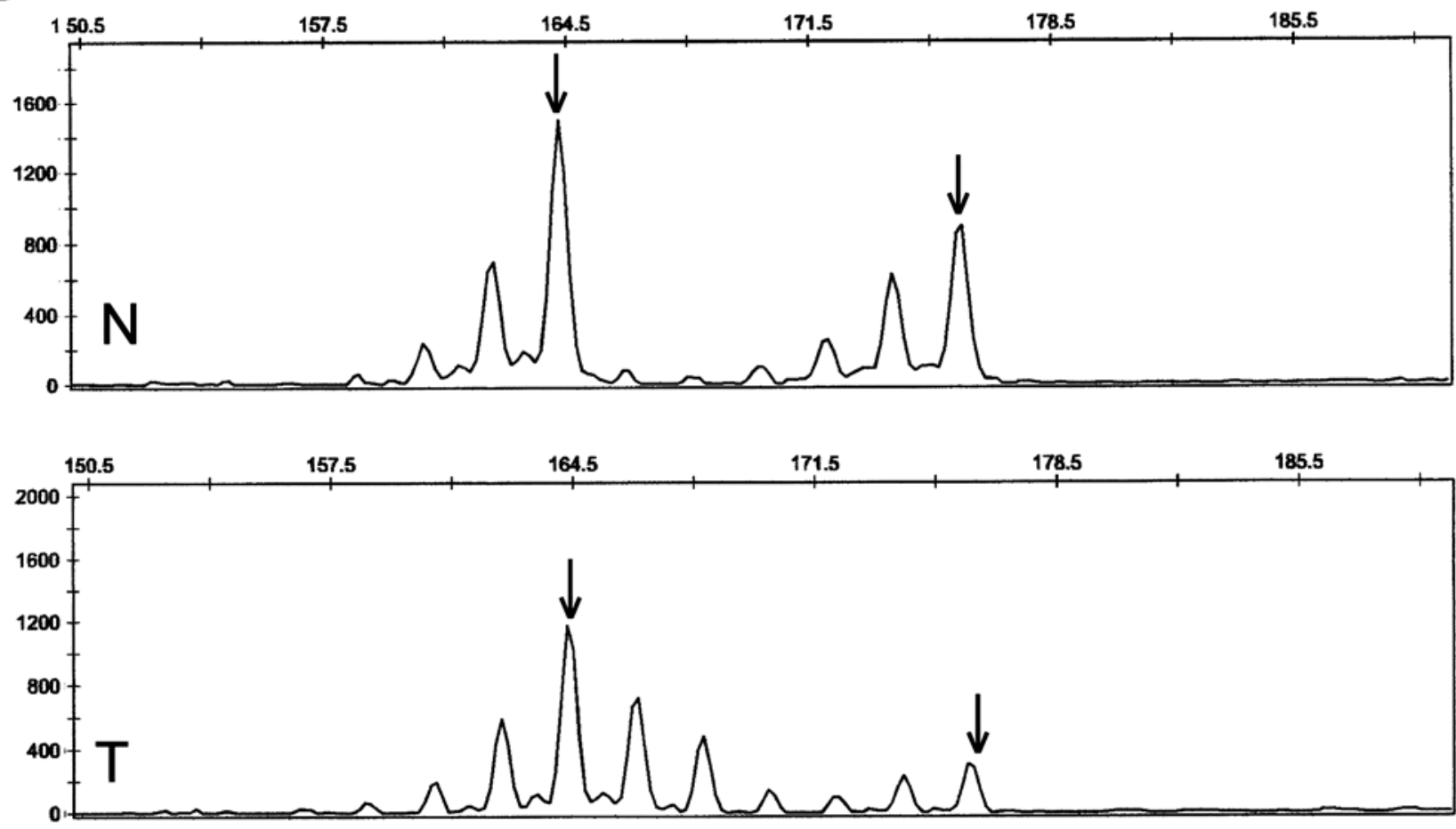

FIGURE 2. Results of MSI analysis for representative loci from case 2. Electropherograms of labeled PCR products of paired tumor (T) and normal (N) DNA are shown for BAT25, a mononucleotide repeat (A) and for D17S250, a dinucleotide repeat (B). PCR product fragment size is represented on the $x$ axis and fluorescence units are represented on the $y$ axis. A single allele is observed at BAT25. Two alleles are observed at D17S250; arrows indicate the individual alleles. For both microsatellite repeats, the tumor DNA shows a novel allele profile that differs from the corresponding allele profile amplified from normal DNA. 
TABLE 2. Clinicopathologic Features of MSI-H and $\mathrm{MSI}^{-}$ Barrett Esophagus-Associated Adenocarcinomas

\begin{tabular}{|c|c|c|c|}
\hline & $\begin{array}{l}\text { MSI-H } \\
(\mathrm{n}=5)\end{array}$ & $\begin{array}{c}\text { MSI }^{-} \\
(n=71)\end{array}$ & $P \ddagger$ \\
\hline Age (y) & $76.2 \pm 5.9$ & $64.4+11.0$ & 0.0060 \\
\hline Sex $($ male \%) & 60 & 89 & \\
\hline \multicolumn{4}{|l|}{ Location } \\
\hline Distal esophagus & $2(40 \%)$ & $32(45 \%)$ & \\
\hline Esophagogastric junction & $3(60 \%)$ & $39(55 \%)$ & \\
\hline \multirow{2}{*}{\multicolumn{4}{|c|}{ pT (Tumor) }} \\
\hline & & & \\
\hline 1 & 0 & $24(34 \%)$ & \\
\hline 2 & $2(40 \%)$ & $14(20 \%)$ & \\
\hline 3 & $3(60 \%)$ & $33(46 \%)$ & \\
\hline \multicolumn{4}{|l|}{ pN (Node) } \\
\hline 0 & $3(60 \%)$ & $34(48 \%)$ & \\
\hline 1 & $2(40 \%)$ & $16(23 \%)$ & \\
\hline 2 & 0 & $11(15 \%)$ & \\
\hline 3 & 0 & $10(14 \%)$ & \\
\hline \multicolumn{4}{|l|}{ pM (Metastasis) } \\
\hline 1 & 0 & $3(4.2 \%)$ & \\
\hline $\mathrm{X}$ & $5(100 \%)$ & $68(96 \%)$ & \\
\hline \multicolumn{4}{|l|}{ pG (Grade) } \\
\hline 1 & 0 & $4(5.6 \%)$ & \\
\hline 2 & $1(20 \%)$ & $32(45 \%)$ & \\
\hline 3 & $4(80 \%)$ & $35(49 \%)$ & \\
\hline $\begin{array}{l}\text { Lymphovascular invasion } \\
\text { (positive \%) }\end{array}$ & 100 & 49 & 0.056 \\
\hline Perineural invasion (positive $\%$ ) & 40 & 39 & \\
\hline Venous invasion (positive \%) & 20 & 24 & \\
\hline Margin status (positive \%) & 0 & 14 & \\
\hline \multicolumn{3}{|l|}{ Histology } & $0.027 \S$ \\
\hline Adenosquamous carcinoma & 0 & $1(1.4 \%)$ & \\
\hline Conventional adenocarcinoma* & $1(20 \%)$ & $52(73 \%)$ & \\
\hline with medullary carcinoma $\dagger$ & $2(40 \%)$ & $1(1.4 \%)$ & \\
\hline with signet ring cell carcinoma & $1(20 \%)$ & $3(4.2 \%)$ & \\
\hline with mucinous carcinoma & 0 & $6(8.4 \%)$ & \\
\hline with mucinous and signet ring cell & $1(20 \%)$ & $8(11 \%)$ & \\
\hline Tumor infiltrating lymphocytes & $42.9 \pm 0.3$ & $5.2 \pm 13.0$ & $<0.0001$ \\
\hline $\begin{array}{l}\text { †ncluding } 2 \text { tumors solely compo } \\
\text { †nly } P \text { values }<0.100 \text { are listed. } \\
\text { \$Conventional adenocarcinoma v }\end{array}$ & medulla & $\begin{array}{l}\text { omponent(s) } \\
\text { arcinoma. }\end{array}$ & \\
\hline
\end{tabular}

pathologists have sought clinicopathologic characteristics of colorectal cancers that correlate with MSI.

Numerous studies have linked MMR deficiency in colorectal cancer to certain morphologic characteristics, such as poor tumor differentiation, medullary type, mucinous type, signet ring cell component, histologic heterogeneity, and increased TILs. ${ }^{17,25,38}$ Recognizing these features may guide pathologists and clinicians in deciding which cases to evaluate for MSI. ${ }^{25}$ With regard to the histologic features of BE-associated invasive carcinomas, as shown in this study, the majority exhibit the histology of moderately or well-differentiated conventional adenocarcinoma. Poorly differentiated carcinomas composed of sheets of epithelial cells with ill-formed glandular lumina, signet ring cell features, and mucinous (colloid) differentiation are uncommon, comprising $5 \%$ to $10 \%$ of cases. ${ }^{26,29}$ Similarly, there are few cases of medullary ${ }^{26,34}$ or lymphoepithelial ${ }^{18,30}$ carcinoma of the esophagus in the literature, and to our knowledge, only a single case of BE-associated adenocarcinoma with lymphoid stroma (medullary carci- noma) has been reported so far. ${ }^{35}$ Conversely, in this study, 4 of the 5 MSI-H tumors exhibited poor tumor differentiation, including medullary morphology, and the remaining case showed moderately differentiated adenocarcinoma with increased TILs. The histologic heterogeneity was also characteristic of microsatellite unstable BE-associated adenocarcinomas, similar to the colonic counterpart.

Of the various histologic features, the medullary morphology seems to be associated with distinct mechanisms of pathogenesis. In our cohort, we used the term "medullary" to refer to a poorly differentiated carcinoma with syncytial islands or complex collections of malignant cells exhibiting prominent infiltration by intraepithelial lymphocytes. It is noted that one can diagnose a "lymphoepithelioma-like" carcinoma when someone confronts an EBV + medullary carcinoma, particularly in other parts of the body, ${ }^{10,16,44}$ and we recognize that our definition of medullary carcinoma overlaps somewhat with "lymphoepithelioma-like" carcinoma in this sense. Using a similar definition, MSI-H status has been reported in $90 \%$ to $100 \%$ of medullary carcinomas of the colon, ${ }^{1,21,32}$ which comprise only $4 \%$ of colorectal cancers. ${ }^{14}$ In the stomach, medullary carcinomas have been observed in association with not only MSI, but also EBV infection. EBER positivity has been identified in $37.5 \%$ to $100 \%$ of gastric medullary carcinomas, especially in the postgastrectomy stomach. $5,6,8,40$ Similarly, MSI-H was much more frequently seen in medullary carcinomas of the stomach than nonmedullary cancers $(41.2 \%$ vs $1.6 \%) .{ }^{24}$ In the esophagus and esophagogastric junction, $\mathrm{Wu}$ et $\mathrm{al}^{46}$ reported the association of MSI and medullary carcinoma. They found 3 $(60 \%)$ of 5 tumors with MSI-H exhibiting features of medullary carcinoma with lymphoid infiltrate in their cohort of 92 cases. The cohort, however, included both BEassociated and non-BE tumors, and the authors did not clearly specify the presence or absence of the BE background in those 3 cases. In our study consisting solely of BEassociated adenocarcinomas, $2(67 \%)$ of the 3 tumors with a medullary carcinoma component showed MSI-H. Interestingly, the remaining one case was positive for EBER.

The presence of MSI raises the possibility of HNPCC, as carcinomas arising in the setting of germline mutation in MMR genes, particularly $h M S H 1$ and $h M S H 2$, usually exhibit MSI-H. ${ }^{33,39}$ In fact, 1 microsatellite unstable BE-associated adenocarcinoma with loss of $\mathrm{MSH} 2$ protein expression in a patient with a family history of multiple cancers suggestive of HNPCC, has been reported. ${ }^{13}$ Among patients who do not manifest HNPCC (sporadic cases), MSI-H is often the consequence of promoter methylation (and subsequent silencing) of $h M L H 1,{ }^{41}$ and is often associated with BRAF mutation. Conversely, HNPCC seldom exhibits the $\mathrm{CpG}$ island methylator phenotype or $B R A F$ mutation. ${ }^{28}$ In this study, all 5 cases with MSI-H tumor showed loss of MLH1 expression with preserved MSH2 nuclear expression in tumor cells and $h M L H 1$ promoter methylation was found in 4 cases, whereas none showed BRAF mutations. Although the possibility of concurrent germline mutation and promoter methylation of $h M L H 1$ cannot be excluded, ${ }^{9}$ 

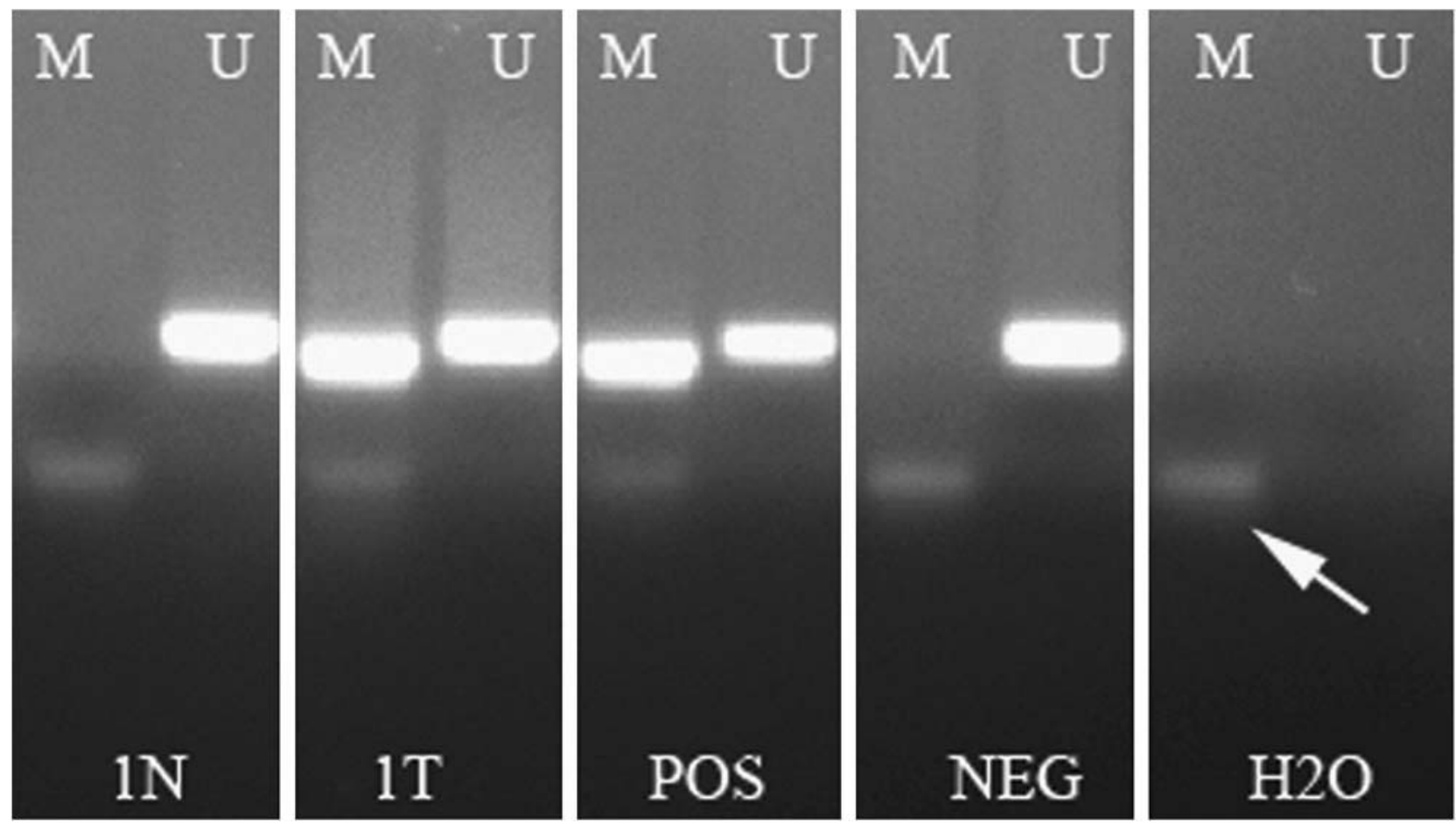

FIGURE 3. Methylation-specific PCR analysis for $h M L H 1$ promoter. Representative normal ( $1 \mathrm{~N}$ ) tissue results for case 1 show only unmethylated $(U)$ but no methylated (M) specific PCR product, whereas the respective tumor (1T) sample for case 1 shows both unmethylated $(U)$ and methylated $(M)$ specific PCR products. A positive methylated DNA sample (POS) and negative unmethylated control (NEG) are also shown. $\mathrm{H}_{2} \mathrm{O}$ represents the water control. The white arrow indicates input primers.

given the advanced age at presentation and the absence of significant family or personal history suggesting HNPCC, these 5 MSI-H tumors most likely represent sporadic MSI$\mathrm{H}$ tumors. ${ }^{38}$ The etiology of MLH1 protein expression loss associated with MSI-H is yet to be determined in the remaining one case; however, given the clinical profile (Table 1), the possibility of HNPCC may be less likely.

The survival advantages (and lower tumor stage) associated with MSI-H that have been reported in the colonic counterpart ${ }^{39}$ and in the esophagus ${ }^{46}$ were not confirmed in this study. There was a trend toward the microsatellite unstable BE-associated adenocarcinomas presenting with a larger tumor and at a more advanced stage than those with preserved MMR protein expression, although there was no difference in outcomes between the 2 groups. BE-associated adenocarcinomas are generally found at a less advanced stage than non-Barrett adenocarcinomas; this is most likely due to surveillance protocols for BE and/or reflux symptoms. ${ }^{31}$ Thus, the results of this study may indicate differences in biology between microsatellite unstable and microsatellite stable tumors in the background of BE. However, further larger-scale studies are warranted to clarify survival in patients with a MSH-H BE-associated adenocarcinoma.

One of the limitations of our study is that we did not conduct MSI PCR testing in tumors with preserved MMR protein expression. Although we cannot exclude the possibility that such cases might harbor a mutant MMR gene that yields a nontruncated protein, which retains the epitope recognized by IHC, given the high correlation between MSI IHC and PCR, ${ }^{15}$ it is less likely that those cases with preserved protein expression would show an MSI-H profile by PCR.

In conclusion, MSI-H is rare in BE-associated adenocarcinomas (6.6\% in this series) but is associated with clinicopathologic features fairly similar to sporadic microsatellite unstable colorectal cancers. Given the growing evidence that indicates lack of benefits from adjuvant therapy with 5-FU in the colonic counterpart, it may be important to identify MSI-H in BE-associated adenocarcinomas, as they are commonly treated with similar chemotherapeutic agents. The results of this study suggest medullary morphology, histologic heterogeneity, and/or increased TILs to be clues to MSI in not only colorectal cancers but also in BE-associated adenocarcinomas. On account of its scarcity, the survival impact of MSI in BEassociated adenocarcinomas still needs to be more clearly defined in larger scale studies.

\section{ACKNOWLEDGMENTS}

The authors thank the James Homer Wright Laboratory of Pathology of the Massachusetts General Hospital and the Emory University Department of Pathology laboratory.

\section{REFERENCES}

1. Alexander J, Watanabe $\mathrm{T}, \mathrm{Wu} \mathrm{T}-\mathrm{T}$, et al. Histopathological identification of colon cancer with microsatellite instability. Am J Pathol. 2001;158:527-535. 
2. American Cancer Society. Cancer facts and figures 2010. 2010. Available at: http://www.cancer.org/Research/CancerFactsFigures/ CancerFactsFigures/cancer-facts-and-figures-2010. Accessed October 23, 2010.

3. American Joint Committee on Cancer. Part III: Digestive System. Chapter 10: Esophagus and Esophagogastric Junction. In: Edge SB, Byrd DR, et al. eds. Cancer Staging Manual. New York, NY: Springer-Verlag; 2010;103-115.

4. Boland CR, Thibodeau SN, Hamilton SR, et al. A National Cancer Institute Workshop on microsatellite instability for cancer detection and familial predisposition: development of international criteria for the determination of microsatellite instability in colorectal cancer. Cancer Res. 1998;58:5248-5257.

5. Bordi C, D'Adda T, Azzoni C, et al. Criteria for malignancy in gastrointestinal endocrine tumors. Endocr Pathol. 2006;17:119-129.

6. Boubaker J, Jouini M, Ben Haha Bellil S, et al. Gastric cancer with lymphoid stroma: a rare form associated with Epstein-Barr virus: five cases. Gastroenterol Clin Biol. 2002;26:523-525.

7. Cameron AJ, Lomboy CT, Pera M, et al. Adenocarcinoma of the esophagogastric junction and Barrett's esophagus. Gastroenterology. 1995; 109:1541-1546.

8. Chapel F, Fabiani B, Davi F, et al. Epstein-Barr virus and gastric carcinoma in Western patients: comparison of pathological parameters and p53 expression in EBV-positive and negative tumours. Histopathology. 2000;36:252-261.

9. Cunningham JM, Christensen ER, Tester DJ, et al. Hypermethylation of the hMLH1 promoter in colon cancer with microsatellite instability. Cancer Res. 1998:58:3455-3460.

10. Dacic S, Lomago D, Hunt JL, et al. Microsatellite instability is uncommon in lymphoepithelioma-like carcinoma of the lung. Am J Clin Pathol. 2007;127:282-286.

11. Daly JM, Karnell LH, Menck HR. National cancer data base report on esophageal carcinoma. Cancer. 1996;78:1820-1828.

12. Evans SC, Gillis A, Geldenhuys L, et al. Microsatellite instability in esophageal adenocarcinoma. Cancer Lett. 2004;212:241-251.

13. Falkenback D, Johansson J, Halvarsson B, et al. Defective mismatchrepair as a minor tumorigenic pathway in Barrett esophagusassociated adenocarcinoma. Cancer Genet Cytogenet. 2005;157:82-86.

14. Gatalica Z, Torlakovic E. Pathology of the hereditary colorectal carcinoma. Fam Cancer. 2008;7:15-26.

15. Gologan A, Sepulveda AR. Microsatellite instability and DNA mismatch repair deficiency testing in hereditary and sporadic gastrointestinal cancers. Clin Lab Med. 2005;25:179-196.

16. Herath $\mathrm{CH}$, Chetty R. Epstein-Barr virus-associated lymphoepithelioma-like gastric carcinoma. Arch Pathol Lab Med. 2008:132:706-709.

17. Hewish M, Lord CJ, Martin SA, et al. Mismatch repair deficient colorectal cancer in the era of personalized treatment. Nat Rev Clin Oncol. 2010;7:197-208.

18. Kijima Y, Hokita S, Takao S, et al. Epstein-Barr virus involvement is mainly restricted to lymphoepithelial type of gastric carcinoma among various epithelial neoplasms. J Med Virol. 2001;64:513-518.

19. Koppert LB, Wijnhoven BP, van Dekken H, et al. The molecular biology of esophageal adenocarcinoma. J Surg Oncol. 2005;92:169-190.

20. Kulke MH, Thakore KS, Thomas G, et al. Microsatellite instability and hMLH1/hMSH2 expression in Barrett esophagus-associated adenocarcinoma. Cancer. 2001;91:1451-1457.

21. Lanza G, Gafà R, Matteuzzi M, et al. Medullary-type poorly differentiated adenocarcinoma of the large bowel: a distinct clinicopathologic entity characterized by microsatellite instability and improved survival. J Clin Oncol. 1999;17:2429.

22. Lanza G, Gafa R, Maestri I, et al. Immunohistochemical pattern of MLH1/MSH2 expression is related to clinical and pathological features in colorectal adenocarcinomas with microsatellite instability. Mod Pathol 2002;15:741-749.

23. Loukola A, Eklin K, Laiho P, et al. Microsatellite marker analysis in screening for hereditary nonpolyposis colorectal cancer (HNPCC). Cancer Res. 2001;61:4545-4549.

24. Lü B-J, Lai M, Cheng L, et al. Gastric medullary carcinoma, a distinct entity associated with microsatellite instability-H, prominent intraepithelial lymphocytes and improved prognosis. Histopathology. 2004:45:485-492.
25. Lynch HT, Lynch JF, Lynch PM, et al. Hereditary colorectal cancer syndromes: molecular genetics, genetic counseling, diagnosis and management. Fam Cancer. 2008;7:27-39.

26. Mizutani K, Makuuchi H, Machimura $\mathrm{T}$, et al. Medullary carcinoma with lymphoid infiltration of esophagus. Jpn J Gastroenterol Surg. 1991;24:1033-1036.

27. Muzeau F, Flejou JF, Belghiti J, et al. Infrequent microsatellite instability in oesophageal cancers. Br J Cancer. 1997;75:1336-1339.

28. Ogino S, Nosho K, Kirkner GJ, et al. CpG island methylator phenotype, microsatellite instability, BRAF mutation and clinical outcome in colon cancer. Gut. 2009;58:90-96

29. Paraf F, Flejou JF, Pignon JP, et al. Surgical pathology of adenocarcinoma arising in Barrett's esophagus: analysis of 67 cases. Am J Surg Pathol. 1995;19:183-191.

30. Rampado S, Bocus P, Battaglia G, et al. Endoscopic ultrasound: accuracy in staging superficial carcinomas of the esophagus. Ann Thorac Surg. 2008;85:251-256.

31. Reid BJ, Li X, Galipeau PC, et al. Barrett's oesophagus and oesophageal adenocarcinoma: time for a new synthesis. Nat Rev Cancer. 2010;10:87-101.

32. Ruschoff J, Dietmaier W, Luttges J, et al. Poorly differentiated colonic adenocarcinoma, medullary type: clinical, phenotypic, and molecular characteristics. Am J Pathol. 1997;150:1815-1825.

33. Shia J, Ellis NA, Paty PB, et al. Value of histopathology in predicting microsatellite instability in hereditary nonpolyposis colorectal cancer and sporadic colorectal cancer. Am J Surg Pathol. 2003;27:1407-1417.

34. Su M, Li XY, Tian DP, et al. Clinicopathologic analysis of esophageal and cardiac cancers and survey of molecular expression on tissue arrays in Chaoshan littoral of China. World $J$ Gastroenterol. 2004;10:2163-2167.

35. Takubo K, Lambie NK. Barrett's adenocarcinoma of the esophagus with lymphoid stroma. J Clin Gastroenterol. 2001;33:141-144.

36. Tepper J, Krasna MJ, Niedzwiecki D, et al. Phase III trial of trimodality therapy with cisplatin, fluorouracil, radiotherapy, and surgery compared with surgery alone for esophageal cancer: CALGB 9781. J Clin Oncol. 2008;26:1086-1092.

37. Urba SG, Orringer MB, Turrisi A, et al. Randomized trial of preoperative chemoradiation versus surgery alone in patients with locoregional esophageal carcinoma. J Clin Oncol. 2001;19:305-313.

38. Vasen HF, Watson P, Mecklin JP, et al. New clinical criteria for hereditary nonpolyposis colorectal cancer (HNPCC, Lynch syndrome) proposed by the International Collaborative group on HNPCC. Gastroenterology. 1999;116:1453-1456.

39. Vilar E, Gruber SB. Microsatellite instability in colorectal cancerthe stable evidence. Nat Rev Clin Oncol. 2010;7:153-162.

40. Wang $\mathrm{HH}, \mathrm{Wu}$ MS, Shun CT, et al. Lymphoepithelioma-like carcinoma of the stomach: a subset of gastric carcinoma with distinct clinicopathological features and high prevalence of EpsteinBarr virus infection. Hepatogastroenterology. 1999;46:1214-1219.

41. Weisenberger DJ, Siegmund KD, Campan M, et al. CpG island methylator phenotype underlies sporadic microsatellite instability and is tightly associated with BRAF mutation in colorectal cancer. Nat Genet. 2006;38:787-793.

42. Whiteman DC, Sadeghi S, Pandeya N, et al. Combined effects of obesity, acid reflux and smoking on the risk of adenocarcinomas of the oesophagus. Gut. 2008;57:173-180.

43. Wijnhoven BP, Lindstedt EW, Abbou M, et al. Molecular genetic analysis of the von Hippel-Lindau and human peroxisome proliferatoractivated receptor gamma tumor-suppressor genes in adenocarcinomas of the gastroesophageal junction. Int J Cancer. 2001;94:891-895.

44. Wilentz RE, Goggins M, Redston M, et al. Genetic, immunohistochemical, and clinical features of medullary carcinoma of the pancreas: a newly described and characterized entity. Am J Pathol. 2000;156:1641-1651.

45. Woerner SM, Benner A, Sutter C, et al. Pathogenesis of DNA repair-deficient cancers: a statistical meta-analysis of putative real common target genes. Oncogene. 2003;22:2226-2235.

46. Wu TT, Watanabe T, Heitmiller R, et al. Genetic alterations in Barrett esophagus and adenocarcinomas of the esophagus and esophagogastric junction region. Am J Pathol. 1998;153:287-294. 